10 — \& Pintner, I. J. (1951). Destruction of chloroplasts by streptomycin. Cold Spring Harbor Symposia Quant. Biol., 16, 113-120.

11. Robbins, W. J., Hervey, A. \& Stebbins, M. E. (1953). Euglena and vitamin $\mathrm{B}_{1 \% .}$ Ann. N. Y. Acad Sci., 56, 818-830.

12. Schopfer, W. H, Grob, E., Besson, G. \& Keller, V. (1952). Recherches sur les inhibiteurs du développement et de la biogenèse des caroténoides. La Streptomycine. Arch. sci. (Geneva), 5, 1-4.

13. Slater, J. V. (1952). The magnesium requirement of Tetrahymena. Physiol. Zoöl., 25, 283-287.

14. Wolken, J. J. \& Palade, G. E. (1953). An electron mi roscope study of two flagellates. Chloroplast structure and variation. Ann. N. Y. Acad. Sci., 56, 873-889.

J. Protozool., 2, 75-80 (1955).

\title{
Tetrahymena from Mexico, Panama, and Colombia, with Special Reference to Sexuality.*
}

\author{
ALFRED M. ELLIOTT and ROBERT E. HAYES \\ Zoology Department, University of Michigan, Ann Arbor, Michigan
}

\begin{abstract}
SUMMARY. Twenty-two $\%$ of the fresh water samples taken from Mexico, Colombia, Panama and the Canal Zone contained $T$. pyriformis. The habitats included springs, roadside ditches, creeks, rivers, ponds, and lakes. They ranged in elevation from sea level to 10,000 feet and in temperature from approximately $8^{\circ}$ to $35^{\circ} \mathrm{C}$. There was no correlation between temperature of habitat and resistance to high temperatures. Thirty-eight $\%$ of the clones isolated contained micronuclei and all but three of these were assigned to variety and mating type. The clones from Mexico all belong to variety 2 , mating type $V$. Those from Colombia belong to mating type IV, variety 9 , a new variety. Five mating types in variety 9 and nine in variety 2 were found in Panama and the Canal Zone. All clones grew in the chemically defined medium that supports the growth of strain $\mathrm{E}$.
\end{abstract}

$\mathbf{R}^{\mathrm{r}}$ ECORDS in the literature indicate that Tetrahymena, (probably $T$. pyriformis) has been seen many times by microscopists in the past two centuries. According to Corliss $(3,4)$ Leeuwenhoek probably saw it in Holland in 1676, Ehrenberg described it from Germany in 1830, and Maupas studied it in Algeria in 1883. Lwoff isolated the now famous axenic strain (GL) in France in 1923, and since that time many strains have been isolated from different areas of the United States. From these reports one must recognize the ubiquitous nature of $T$. pyriformis. In the light of this knowledge it would hardly seem worthwhile to investigate the distribution of this ciliate if the objective were merely to relate its presence or absence in different habitats. The search takes on more significance, however, when consideration is given to the prominent place Tetrahymena occupies at the present time as an experimental animal, first in nutritional studies and now as a potential genetic tool. If the latter studies are to be meaningful a thorough knowledge of the life history of the species must be acquired, and with the discovery of mating types(5) this is possible. In addition to the original variety (6) Gruchy (8) has found seven new varieties from the United States. These eight varieties have been assigned numbers as have mating types determined for each variety. Assuming that the number of varieties in the United

* This investigation was supported by a research grant (PHS G3588C ) from the National Institutes of Health, Public Health Service. Much of the technical work was done by Sannah A. Brask.
States stands at eight, there is no assurance that other varieties might not exist elsewhere in the world. For that reason it seemed worthwhile to extend the search to other areas, specifically tropical America.

Consequently, one of us (A.M.E.) collected water samples from Mexico, Panama, the Canal Zone, and the vicinity of Bogota, Colombia; thus sampling an area extending from the Tropic of Cancer to approximately $5^{\circ}$ north of the equator. A special effort was made to obtain samples from regions of wide temperature and altitude variations. From this study it was hoped that additional information might be gained as to the distribution of the presently known varieties and mating types, and that perhaps new ones might be found. The purpose of this report is to relate the degree of success of this venture.

\section{MATERIALS AND METHODS}

Freshwater samples were taken from springs, roadside ditches, creeks, rivers, ponds and lakes. Bottom mud, together with leaves and other debris, was included with the water sample, which usually consisted of at least $100 \mathrm{ml}$. of material in all. The samples were taken to the laboratory as soon as possible (usually within a few hours) and poured into finger bowls for incubation. Bacto-tryptone, proteose-peptone, or desiccated fat-free milk was sprinkled over the surface of the water. Within 12-24 hours the bacterial popu. lation flourished and concurrently Tetrahymena appeared in great numbers, if present in the original 
sample. Micropipettes were used to transfer single ciliates into slide depressions filled with lettuce medium (1/2 g. of desiccated lettuce to $1000 \mathrm{ml}$. distilled water) seeded with Aerobacter aerogenes. These clonal cultures, following 24 hours of incubation, were transferred into tubes of fresh medium and shipped to the University of Michigan where they were tested for mating reactions.

Before these clones were analyzed for mating type a few cells from each clone were washed in distilled water and then subjected to antibiotics $(250 \mu \mathrm{g} . / \mathrm{ml}$. each of penicillin $\mathrm{G}$ and streptomycin) in order to render them axenic. They were then transferred to tubes of sterile stock medium (1\% tryptone-proteose-peptone broth) and have been maintained continuously in it with monthly transfers. This step is useful since it tends to screen out closely related ciliates but permits Tetrahymena to thrive. No ciliates have been found other than $T$. pyriformis and $T$. vorax, that will grow through several transfers following this treatment. It is possible that some strains of Tetrahymena are also lost through the use of these antibiotics. However, at present the ease of establishing axenic cultures by this means and the convenience of maintaining such cultures seems to outweigh the risk involved.

All clones grow satisfactorily in the chemically defined medium that supports strain $\mathrm{E}(6)$. Obviously, this means that the medium is adequate but it does not imply that all of the nutrilites present are essential for growth. Whether or not any of these strains can grow on less than the 18 nutrilites essential for strain $\mathrm{E}$ and the strains reported earlier (WH6, 14, 52) is being determined at the present time, and will be dealt with in a later report.

The procedure followed in mating tests was similar to that described earlier(6). The matings were carried out in depression slides under semi-aseptic conditions. Since the washed organisms were suspended in distilled water the likelihood of bacterial growth was reduced and strict aseptic conditions were unnecessary. Three preliminary washings of the cells in water doubly distilled through glass hastened the mating reaction. The refractory time was further shortened by maintaining mating mixtures at $30^{\circ} \mathrm{C}$. Twenty-four hour cultures are more likely to yield optimum mating reactions.

Mating usually occurred between 18 and 36 hours after mixing although in some instances it was possible to determine the mating type within 8 hours. In other cases mating did not occur until after 48 hours. Among the clones investigated there was variation, not only in the time required for mating, but also in the mating reaction itself. Some clones failed to mate on a given day but did the following day under identical conditions. This erratic behavior made it neces- sary to repeat all nonreactive mating mixtures several times. Positive matings were repeated at least once. Theoretically, one conjugating pair in a test mixture is all that is required to identify a positive reaction. However, owing to the possibility of accidental spilling of small amounts of culture from one depression to another while handling hundreds of matings, all mixtures containing only a few pairs have been repeated until a strong reaction is noted. Therefore, when a positive reaction is indicated in the data, it means that a strong reaction has been elicited and there is no doubt about the reactivity of the particular clone.

Samples from all clones were routinely treated with an aceto-orcein-gelatin staining schedule in order to determine the presence or absence of micronuclei. In addition samples were similarly stained to study nuclear reorganization during conjugation.

\section{RESULTS \\ Areas Studied}

It should be emphasized at the outset that the collecting program undertaken does not and was not intended to represent a complete survey of Tetrahymena from the geographical areas involved. The samples taken were far too few in number to justify sweeping conclusions about the absence of particular varieties and mating types of Tetrahymena from any given area.

Mexico. Samples were taken from the Rio Grande river at Nuevo Laredo, and at intervals along Highway 85 to Mexico City as shown in Fig. 1. These, together with others collected in the vicinity of Mex-

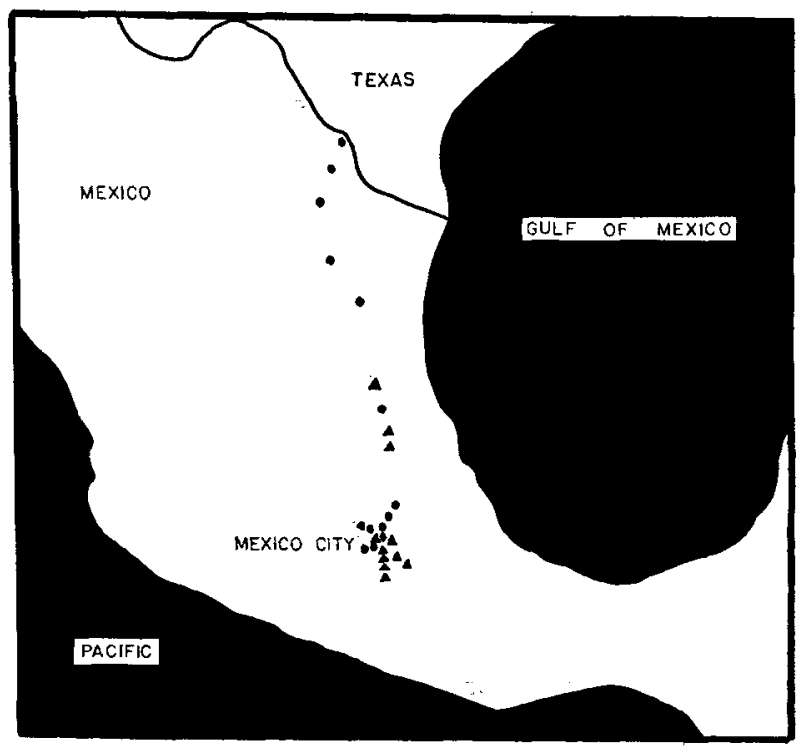

Fig. 1. Sources of water samples taken along Highway 85 from Nuevo Laredo to Mexico. Not all of the negative samples are shown. T. pyriformis present $=\mathbf{\Delta}$; absent $=\mathbf{0}$. 
TABLE I. Samples from Mexico containing T. pyriformis collected $2 / 15 / 54$ to $3 / 2 / 54$.

\begin{tabular}{|c|c|c|c|c|c|}
\hline $\begin{array}{l}\text { Sample } \\
\text { number }\end{array}$ & Location & $\begin{array}{l}\text { Strain } \\
\text { number }\end{array}$ & $\begin{array}{l}\text { Miero- } \\
\text { nuelei }\end{array}$ & $\begin{array}{l}\text { Vari- } \\
\text { ety }\end{array}$ & $\begin{array}{l}\text { Mating } \\
\text { type }\end{array}$ \\
\hline 6 & $\begin{array}{l}\text { Rio Tamesi irriga- } \\
\text { tion ditch near } \\
\text { El Mante, elev. } \\
995 \mathrm{ft} \text {. }\end{array}$ & $1-7$ & 0 & - & - \\
\hline 8 & $\begin{array}{l}\text { Rio Moctezuma at } \\
\text { Tamazunehale, } \\
\text { elev. } 394 \text { ft. }\end{array}$ & $8-14$ & 0 & - & - \\
\hline 9 & $\begin{array}{l}\text { Rio Moctezuma, } 5 \\
\text { miles south of } \\
\text { Tamazunehale, } \\
\text { elev. } 394 \mathrm{ft} \text {. }\end{array}$ & $15-30$ & 0 & - & - \\
\hline 10 & $\begin{array}{l}\text { Xochimileo, float- } \\
\text { ing gardens, } \\
\text { elev. } 7349 \mathrm{ft} \text {. }\end{array}$ & $\begin{array}{l}31-35 \\
36,38 \\
37,39-11\end{array}$ & $\begin{array}{l}0 \\
+ \\
0\end{array}$ & $\stackrel{-}{?}$ & $\stackrel{-}{-}$ \\
\hline 11 & $\begin{array}{l}\text { Biological station } \\
\text { pond, Chapulte- } \\
\text { pec Park, elev. } \\
7349 \mathrm{ft} \text {. }\end{array}$ & $42-50$ & + & 2 & $\mathrm{~V}$ \\
\hline 12 & $\begin{array}{l}\text { Contreras Canyou, } \\
\text { elev. } 10,000 \mathrm{ft} .\end{array}$ & $51-54$ & + & 2 & $\mathrm{~V}$ \\
\hline 14 & $\begin{array}{l}\text { Contreras Canyou, } \\
\text { elev. } 8,000 \mathrm{ft} \text {. }\end{array}$ & lost & & & \\
\hline .16 & $\begin{array}{l}\text { Contreras Canyon, } \\
\text { elev. } 7,500 \mathrm{ft} .\end{array}$ & lost & & & \\
\hline 18 & $\begin{array}{l}\text { Contreras Canyou, } \\
\text { elev. } 7,349 \mathrm{ft} .\end{array}$ & lost & & & \\
\hline 19 & $\begin{array}{l}\text { Thalpan, Fuentes } \\
\text { Brotantes, elev. } \\
7,349 \mathrm{ft} \text {. }\end{array}$ & $\begin{array}{l}55-56 \\
57\end{array}$ & $\begin{array}{c}0 \\
+\end{array}$ & $\bar{q}$ & $\bar{q}$ \\
\hline 22 & $\begin{array}{l}\text { Rio Consulado, } \\
\text { elev. } 7,349 \mathrm{ft} .\end{array}$ & lost & & & \\
\hline
\end{tabular}

(All strain numbers in this table are to be preceded by the letters TC.)

ico City, were studied in the Laboratory of Protozoology, Instituto Salubridad y Enfermidades Tropicales. ${ }^{1}$ The results of the analysis for variety, mating type and micronuclear condition are recorded in Table I.

Of the 39 water samples taken, $11(28 \%)$ were positive for $T$. pyriformis. Four of the samples were lost in transit. From the remaining 7 samples 62 clones were isolated of which $16(26 \%)$ proved to contain micronuclei. All amicronucleate strains failed to mate under the conditions of the testing program. Of the 16 micronucleate clones 13 belong to variety 2 , mating type $V$ according to Gruchy's (8) mating system. The remaining three clones failed to mate with any types in variety 2 or with mating types in any of the other varieties. These may represent a new variety for which other mating types have not yet been found, or may be sexually immature members of one of the established varieties.

1 The facilities of the Instituto Salubridad y Enfermidades Tropicales were made available through the courtesy of Professor E. Beltran and Dr. E. G. Ballesteros. Without these facilities the isolation of clones would have been very difficult. To these gentlemen is owed a debt of gratitude.
It is of interest to note that clones isolated from water taken at 10,000 feet elevation are of the same mating type and variety as those taken from 7,300 feet. The temperature difference between these two collection sites was considerable (approximately $20^{\circ} \mathrm{C}$ ). Unfortunately clones isolated from the low (394 feet) desert region (sample number 9), where the temperature is high $\left(30^{\circ} \mathrm{C}\right.$ or above) were amicronucleate and failed to conjugate.

Panama and the Canal Zone. Samples were taken in the Canal Zone and adjacent areas of Panama as indicated in Fig. 2. Clone cultures were isolated in the Gorgas Memorial Laboratory, Panama City. ${ }^{2}$ Seventy-two samples were taken, of which $22(30 \%)$ were positive for $T$. pyriformis. Two samples contained $T$. vorax (strain R.P.) (7), in addition to $T$. $p y$ riformis. The results of the analysis for micronuclei, variety, and mating type are shown in Table II.

Greater success was achieved in returning viable cultures from Panama and the Canal Zone. Of the clones isolated 104 survived and of these $82(79 \%)$ possessed micronuclei. All but 19 of the clones belong to variety 2 . In addition to the ten mating types discovered by Gruchy (unpublished) for variety 2 in the United States, a new mating type (XI) was found from these collections. However, mating types II and VI of this variety were not found. Mating types I, IV, V, VII, and XI occurred in two samples, III, VIII, IX, and $\mathrm{X}$ in one sample.

The remaining 19 clones represent a new variety, 9. Five mating types were found in this variety, types III and V occurred in two samples and I, II, and IV in one sample each.

Colombia. Samples were taken in the vicinity of Bogota, ${ }^{3}$ 8,300 feet above sea level and approximately $5^{\circ}$ north of the equator. The streams and roadside ditches from which the samples were taken empty into the Bogota river, a tributary of the Magdalena river system that flows north and ultimately empties into the Caribbean Sea. The samples were flown back to Panama where clones were isolated. Results of the analysis of this material are shown in Table III.

Of the 24 samples taken, $7(29 \%)$ contained $T$. pyriformis. From these 7 samples 101 clones were isolated but only 4 contained micronuclei. All 4 of these belonged to mating type IV of variety 9 , found earlier in Panama.

\footnotetext{
2 The facilities of the Gorgas Memorial Laboratory were made available, without which this work would have been very difficult, if not impossible. To Dr. Herbert C. Clarke, Director, Dr. A. G. Fairchild, and Dr. Harold Trapido, deep appreciation is expressed.

3 Through the help of Professor Hernando Correal, Dr. Roberto Galan Ponce, and Dr. Hector Perez Silva the task of making collections was made very pleasant. To these men sincere gratitude is extended.
} 


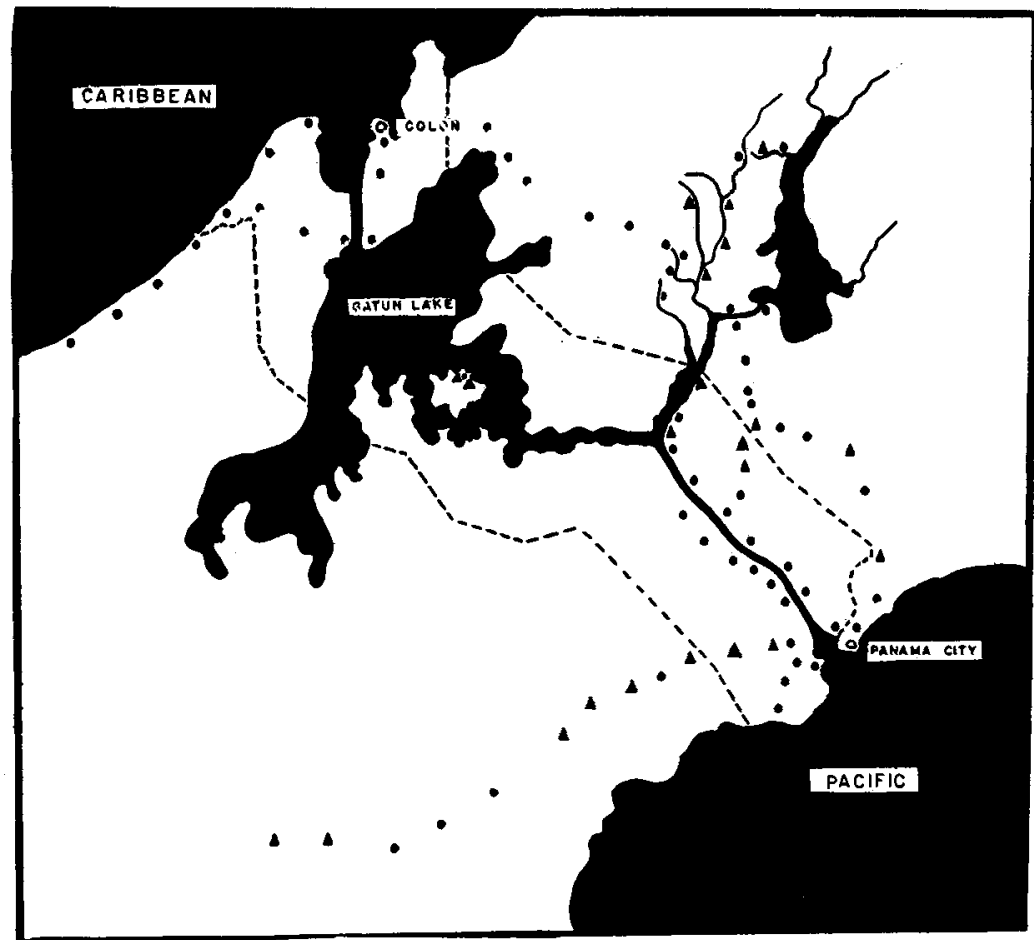

Fig. 2. Sources of water samples taken in the Canal Zone and the Republic of Panama. Locations are given for some negative samples that were lost. T. pyriformis present $=\mathbf{\Delta}$; absent $=\mathbf{0}$.

\section{Temperature and Habitat in Relation to Growth}

Since clones were isolated from habitats of widely varying temperatures (approximately $30^{\circ} \mathrm{C}$. in Panama to $15^{\circ} \mathrm{C}$. in Contreras Canyon, Mexico) it was thought worthwhile to determine the temperature sensitivity, after 72 hours of incubation, of 11 representative strains taken from these contrasting environments. Accordingly, strains 8, 36, 51, 57, 74, 85, 93, $102,123,147$, and 256 were investigated. The classical strain $\mathrm{E}$ was also included in the study.

No strains grew at the highest temperature $\left(43^{\circ} \mathrm{C}\right.$.) whereas all grew at $16^{\circ} \mathrm{C}$. and $25^{\circ} \mathrm{C}$. The critical temperature was $37^{\circ} \mathrm{C}$. where 7 of the 12 strains tested grew but none of these reached the population density attained at the lower temperatures. The amicronucleate strains $(8,102,256, \mathrm{E})$ could not survive $37^{\circ} \mathrm{C}$; only one of the micronucleate clones (147) failed to survive this temperature. One might think that strains isolated from environments which are continuously warm would survive the higher temperatures better than those found in cooler waters. This was not the case since strains 8,102 , and 147 collected from warm habitats could not survive $37^{\circ} \mathrm{C}$., whereas strain 51 from a cold mountain stream at 10,000 feet elevation grew fairly well at $37^{\circ} \mathrm{C}$. Within the limitations of this experiment it appears that factors other than a long continued exposure to high temperature of the environment might be involved in the mechanism that permits organisms to survive high temperatures.

\section{Variety 9-A New Variety}

From water samples collected in Panama and Colombia a new variety was discovered which has been assigned the number 9 . It was found in four samples from Panama and in two from the vicinity of Bogota (Tables II, III). This variety has not been reported from any of the collections made in the United States, Canada, and Mexico.

\section{DISCUSSION}

Extensive distribution studies have been made for only a few species of protozoa and have been stimulated primarily by an interest in the possible use of the organisms for studies in genetics. Perhaps the most complete report is that for the distribution of the varieties of Paramecium aurelia, reviewed by Beale(1). Of the nine varieties reported, eight occur in the United States. Varieties 1, 2, 4, and 6 are widely scattered, having been recorded from North America, South America, Western Europe, Japan, and India. The recently reported variety $9(2)$ has been found only in France and Scotland. The extensive studies of Jennings, Chen, and Wichterman (reviewed by Wichterman(10)) likewise indicate the wide distribution of 
the six varieties of $P$. bursaria. The distribution studies of Paramecium resemble those reported here for $T$. pyriformis in that all or nearly all of the varieties are found in extensively studied areas, whereas few are

TABIE II. Samples from Panama and Canal Zone containing 7 . pyriformis collected $3 / 25 / 54$ to $4 / 28 / 54$

(Execpt where otherwise indicated elevation was under $200 \mathrm{ft}$.)

\begin{tabular}{|c|c|c|c|c|c|}
\hline $\begin{array}{l}\text { Simplic } \\
\text { number }\end{array}$ & Location & $\begin{array}{l}\text { Strain } \\
\text { number }\end{array}$ & $\begin{array}{l}\text { Micro- } \\
\text { muclei }\end{array}$ & $\begin{array}{l}\text { Vari- } \\
\text { ety }\end{array}$ & $\begin{array}{c}\text { Mating } \\
\text { type }\end{array}$ \\
\hline 40 & $\begin{array}{l}\text { Canal Zone, Forest } \\
\text { Preserve, small } \\
\text { stream }\end{array}$ & $63-67$ & 0 & - & - \\
\hline 41 & $\begin{array}{l}\text { Canal Zone, Forest } \\
\text { Preserve, small } \\
\text { stream }\end{array}$ & lost & & & \\
\hline 43 & $\begin{array}{c}\text { Trans Istmica Higl- } \\
\text { way, Rio Chilibre }\end{array}$ & $68-73$ & 0 & - & - \\
\hline 45 & $\begin{array}{l}\text { Thatcher Highway, } \\
\text { small stream }\end{array}$ & lost & & & \\
\hline 46 & $\begin{array}{l}\text { Thatcher Highway, } \\
\text { Rio Caseres }\end{array}$ & $74-83$ & + & 2 & I \\
\hline 47 & $\begin{array}{l}\text { Thatcher Highway, } \\
\text { Rio Aquacate }\end{array}$ & $\begin{array}{l}84,88-91 \\
85,92 \\
86 \\
87\end{array}$ & $\begin{array}{l}+ \\
+ \\
+ \\
+\end{array}$ & $\begin{array}{l}9 \\
2 \\
2 \\
2\end{array}$ & $\begin{array}{l}\mathrm{V} \\
\text { VII } \\
\mathrm{X} \\
\text { VIII }\end{array}$ \\
\hline 48 & $\begin{array}{l}\text { Thateher Highway, } \\
\text { Rio Bernardino }\end{array}$ & $93-95$ & + & 2 & XI \\
\hline 49 & $\begin{array}{l}\text { Thateher Highway, } \\
\text { Rio Caimito }\end{array}$ & $96-101$ & + & 2 & $X I$ \\
\hline 50 & $\begin{array}{l}\text { Thatcher Highway, } \\
\text { Rio Martill Siln- } \\
\text { eher }\end{array}$ & $\begin{array}{l}102,104 \\
103,105- \\
111\end{array}$ & $\begin{array}{l}0 \\
+\end{array}$ & $\overline{9}$ & $\vec{I}$ \\
\hline 61 & $\begin{array}{l}\text { Trians Istmiea } \\
\text { Highway, Rio } \\
\text { Gatumeillo }\end{array}$ & $112-117$ & + & 2 & IV \\
\hline 63 & $\begin{array}{l}\text { Gamboa, Rio } \\
\text { Cliagres }\end{array}$ & $118-122$ & + & 2 & IV \\
\hline \multirow[t]{2}{*}{64} & $\begin{array}{l}\text { Rio Honda, tribu- } \\
\text { tary of Chagres }\end{array}$ & $\begin{array}{c}123,127 \\
124-126 \\
129,130\end{array}$ & + & $\begin{array}{l}2 \\
2\end{array}$ & $\begin{array}{l}I \\
V\end{array}$ \\
\hline & & 128 & + & 2 & VII \\
\hline 67 & $\begin{array}{l}\text { Rio Linon, tribu- } \\
\text { tary of Chalgres }\end{array}$ & $131-137$ & 0 & - & - \\
\hline 68 & $\begin{array}{l}\text { Rio Limon, far- } \\
\text { ther upstream }\end{array}$ & $138-146$ & + & 2 & $V$ \\
\hline $72-73$ & Barro Colorado & lost & & & \\
\hline $7 t$ & $\begin{array}{c}\text { Gatun Lake, near } \\
\text { Barro Colorado }\end{array}$ & lost & & & \\
\hline 78 & $\begin{array}{l}\text { Rio Chagres, Ma- } \\
\text { larial Control } \\
\text { Camp }\end{array}$ & $147-153$ & + & 9 & II \\
\hline 95 & $\begin{array}{l}\text { Thateher Highway, } \\
\text { near La Chorrera }\end{array}$ & lost & & & \\
\hline 99 & $\begin{array}{l}\text { Thiteher H'low'y, } \\
\text { noar Serro Cam- } \\
\text { mana, cles. } 2,000 \\
\text { te. }\end{array}$ & 154,155 & + & 2 & III \\
\hline 100 & $\begin{array}{l}\text { Thateher H'hw'y, } \\
\text { near Serro Cami- } \\
\text { pana, elev. } 1,000 \\
\text { ft. }\end{array}$ & $\begin{array}{l}156,158 \\
157,159 \\
160\end{array}$ & $\begin{array}{l}+ \\
0 \\
+\end{array}$ & $\frac{9}{9}$ & $\frac{\text { III }}{\text { IV }}$ \\
\hline .135 & $\begin{array}{l}\text { Rio Chagres, near } \\
\text { Madden Lake }\end{array}$ & $161-166$ & + & 2 & IX \\
\hline
\end{tabular}

(All strain numbers in this table are to be preeded by the letters TC.)
TABLE III. Samples from the vicinity of Bogota, Colombia containing 7 . pyriformis collected $4 / 22 / 54$ to $4 / 24 / 54$. (Elevation 8,300 ft.)

\begin{tabular}{|c|c|c|c|c|c|}
\hline $\begin{array}{l}\text { Sample } \\
\text { number }\end{array}$ & Location & $\begin{array}{l}\text { Strain } \\
\text { number }\end{array}$ & $\begin{array}{l}\text { Miero- } \\
\text { nuclei }\end{array}$ & $\begin{array}{l}\text { Vari- } \\
\text { ety }\end{array}$ & $\begin{array}{l}\text { Mating } \\
\text { type }\end{array}$ \\
\hline 106 & $\begin{array}{l}\text { Rio Bogota, sev- } \\
\text { eral miles up- } \\
\text { stream }\end{array}$ & $167-187$ & 0 & - & - \\
\hline 107 & Sime & $188-204$ & 0 & - & - \\
\hline 108 & Sime & $205-218$ & 0 & - & - \\
\hline 109 & $\begin{array}{l}1 \text { mile northwest, } \\
\text { irrigation ditch }\end{array}$ & $219-243$ & 0 & - & - \\
\hline 118 & $\begin{array}{l}3 \text { miles northwest, } \\
\text { small tributary } \\
\text { of Rio Bogota }\end{array}$ & $244-255$ & 0 & - & 一 \\
\hline 124 & $\begin{array}{l}15 \text { mi. nortliwest, } \\
\text { irrigation ditch }\end{array}$ & $\begin{array}{l}256,259 \\
257,258 \\
260\end{array}$ & $\begin{array}{l}0 \\
+\end{array}$ & $\overline{9}$ & $\overline{I V}$ \\
\hline 129 & $\begin{array}{l}10 \text { mi. northwest, } \\
\text { small tributary } \\
\text { of Rio Bogota }\end{array}$ & $\begin{array}{l}261-266 \\
267\end{array}$ & $\begin{array}{l}0 \\
+\end{array}$ & $\overline{9}$ & $\overrightarrow{\text { IV }}$ \\
\hline
\end{tabular}

(All strain numbers in this table are to be preceded by the letters TC.)

generally found in the less extensively studied areas. It will not be possible to make positive statements regarding habitat and distribution until much more data are available from representative areas of the earth that support these protozoa.

Water samples taken in this survey usually contained only one of the two varieties of $T$. pyriformis reported in this paper. One exception occurred in sample 47 where both varieties were found. On the other hand, more than one mating type was often found in a single sample. Sample 47 contained mating types VII, VIII, and X of variety 2 , in addition to type $\mathrm{V}$ of variety 9 . Likewise, mating types I, V, and VII of variety 2 were present in sample 64, and types III and IV of this variety in sample 100 . It is probably true that in most instances one mating type is predominant in the sample, thereby increasing the likelihood of picking it up during isolations. Competition for survival between strains representing different mating types can be studied in laboratory cultures. Preliminary observations show that when strains WH-6 and WH-14 (mating types $I$ and II of variety 1 were inoculated in equal numbers into a tube of broth, within a few days the mating type II strain was dominant and in subsequent subcultures the type I strain was completely eliminated. Whether this apparent competition between two strains can be correlated with mating type remains to be seen. Also, just how this observation fits in with the situation in a single natural habitat, where all mating types presumably exist, is not at all evident. A great deal needs to be learned about competition between intra- and intervarietal mating types in the laboratory and also in nature.

The results of routine staining and preliminary ob- 
servations seem to indicate no major morphological differences among the many clones studied, aside from the presence or absence of a micronucleus. Tetrahymena of the two varieties ( 2 and 9 ) found in these collections seem to be identical to one another and to those of variety 1 . Moreover, they show no apparent morphological differences when compared to the six other varieties (Gruchy-personal communication). Whether there are physiological differences, other than sexual, is not known at this time. Small morphological and physiological differences may be found when careful analyses are made. This would seem likely in the light of the varietal differences reported for Paramecium aurelia $(9)$.

\section{Strain Nomenclature}

Corliss in his excellent review(4) discussed the confusion that exists in the literature concerning names and strain designations of Tetrahymena. He compiled a list of extant strains known to him of the several species in axenic culture and emphasized the necessity for some precise and uniform system of strain nomenclature. With this the writers wholeheartedly agree and feel that a standard form of strain designation should be proposed.

It is suggested that assigned and uniformly used lettered strain designations be adopted. Such a letter designation, preferably consisting of two letters, could apply to either a single strain, as it has in the past, or to a series of strains such as presented in this paper. If a series of strains be identified by one pair of code letters, the letters will be followed by numbers to distinguish between the members of the series. For example, all of the strains of $T$. pyriformis collected on the trip described here are placed in the TC series (for "Tropic of Cancer"). Individual strains of this series are described as TC1, TC2, etc.

To avoid confusion a check list should be maintained showing which letter combinations have already been taken and which combinations are still available for future collections. The authors will be glad to assist persons who are interested in making collections and assigning letter designations to them.

\section{REFERENCES}

1. Beale, G. H. (1954). The Genetics of Paranecium aurelia. Cambridge University Press, Cambridge.

2. Beale, G. H. \& Schneller, M. (1954). A ninth variety of Paramecium aurelia. J. Gen. Microbiol., 11, 57-58.

3. Corliss, J. O. (1952). Comparative studies on holotrichous ciliates in the Colpidium-Glaucoma-Leucophrys-Tetrahymena group. I. General considerations and history of strains in pure culture. Trans. Am. Microscop. Soc., 71, 159-184.

4. (1954). The literature on Tetrahymena: Its history, growth, and recent trends. J. Protozool., 1, 156-169.

5. Elliott, A. M. \& Gruchy, D. F. (1952). The occurrence of mating types in Tetrahymena. (Abstr.). Biol. Bull., 103, 301.

6. Elliott, A. M. \& Hayes, R. E. (1953). Mating types in Tetrahymena. Biol. Bull., 105, 269-284.

7. - (1954). A conjugating strain of Tetrahymena vorax. (Abstr.) Biol. Bull, , 107, 309.

8. Gruchy, D. F. (1954). The system of breeding relations in Tetrahymena pyritormis. (Abstr.) J. Protozool., 1, (Supplement), 2.

9. Sonneborn, T. M. (1947). Recent advances in the genetics of Paramecium and Euplotes. Advances in Genet., 1, 263-358.

10. Wichterman, R. (1953). The Biology of Paramecium. Blakiston Co., New York. 